internal combustion engines, and also various papers in engineering journals. He has contributed considerably to the science of heat transmission and the flow of gases, and to the theory of the internal combustion engine applied to modern developments. His interests lie both in fundamental thermodynamics and fluid mechanies, and in applications of the gas turbine prime mover to the propulsion of aircraft, ships and for the generation of power on land. $\mathrm{He}$ is chairman of the Turbines, Jets and Rockets Sub-Committee of the Aeronautical Research Council, chairman of the Mechanical Engineoring Panel of the Ministry of Aircraft Production Gas Turbine Collaboration Committee and chairman of the Submarine Propulsion Sub-Committee of the Admiralty Scientific Advisory Panel.

\section{Sir John Lennard-Jones, K.B.E., F.R.S.}

Atтноugr he has held the Plummer chair of theoretical Chemistry in the University of Cambridge for fourteen years, only for about one half of that time has Sir John Lennard-Jones been the academic mon pure and simple. Since early in the War he has been a Government servant; and his resignation from the post of Director General of Scientific Research (Defence) has just been announced. Sir John first left his university post, to which he is now returning, in 1939, when he joined the Ministry of Supply to take charge of a group of scientific workers. Later, as chief superintendent of armament research, he controlled research being done for all three Fighting Services. His wide experience in the armaments field goes back to the First World War, when he left the R.F.C. as a flying officer to work at the Experimental Station at Orfordness. Latterly, as Director-General of Defence Research, he was in charge of a dozen stations scattered the length and breadth of Britain. Although he is now going back to Cambridge, Sir John will still be connected with the Ministry of Supply, the University having agreed to make his services available on a part-time basis as chief scientific adviser.

\section{Physics at Reading :}

\section{Prof. R. W. Ditchburn}

Prof. R. W. Ditchiurs, who has been appointed to succeed Prof. J. A. Crowther in the chair of physics in tho/fniversity of Reading. (see Nature of March 30, f (N1), graduated at Liverpool. In 1922 he went po dombridge, where he worked under Sir J. J. Aymen in the Cavendish Laboratory on the contivous absorption of light in potassium vapour. $\mathrm{He}$ held the Isaac Newton studentship during 1925-28. In 1928 he was elected fellow of Trinity College, Dublin, and in the following year became Erasmus Smith's professor of natural and experimental philosophy. His researches in Dublin extended his earlier work on the continuous absorption of light in vapours of alkali metals. He also worked on the theory of optical instruments and the properties of thin films. During the War he returned temporarily to England to work for the Admiralty on problems connected with the psycho-physics of vision. Having wide humane interests and a natural capacity for administration, Prof. Ditchburn made opportunity in the midst of an active career as a physicist to shoulder the responsibilities of registrar of the School of Social Studies and to organise a great deal of social work through philanthropic channels. The influx of refugees into Eire during the last ten years much increased the scope of this work. His return to England will be a most opportune accession of administrative and research experience at a time when post-war university re-organisation is just getting under way.

\section{University Grants Committee}

IN a Parlianentary written reply on July 30, the Chancellor of the Exchequer stated that the University Grants Committee ought to play a more positive part jn the expansion and planned development of the universities of Britain, and accordingly it has been given the following new terms of reference :

"To inquire into the financial needs of university education in Great Britain; to advise the Government as to the application of any grants made by Parliament towards meeting them; to collect, examine, and make available information on matters relating to university education at home and abroad; and to assist, in consultation with the universities and other bodies concerned, the preparation and execution of such plans for the development of the universities as may from time to time be required in order to ensure that they are fully adequate to national needs".

\section{Tercentenary of Flamsteed}

THe tercentenary of tho birth of the Revi. John Flamsteed, first Aquón mer Royal and rector of Burstow, Surgey wifinse commemorated at a special evensong at 3.6.p.m. on Sunday, August 18, in Burstow 9 Arch. The present rector, the Rev. A. Fackleds, will conduct the service, after which the A ftyomer Royal, Sir H. Spencer Jones, will give an addfoss on Flamsteed's work. Representatives of the Royal Astronomical Society and other bodies will be present. Flamsteed, who was born on August 19, 1646, at Denby near Derby, was made by Charles II "Our Astronomical Observator" in 1675, and Flamsteed House, at the Royal Observatory, Greenwich, was built for his use. His salary was but small and he had to find his own instruments. His enthusiasm and industry, however, enabled him to overcome these and other difficulties, and he laid well and truly the foundation of the fame of the Observatory. In 1684 he had been given the living of Burstow, and at his death in 1719 he was buried in the chancel of the church. In 1887 the late J. J. Tustin erected the east window and a memorial tablet to his memory. The church is situated about three miles south-west of Horley, and the Reigate-Horley-East Grinstead bus, No. 424 , gives a half-hourly service to within half a mile of it.

\section{Centenary of John Oyifens}

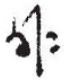

THE Manchespr Gnatian of July 27 contained an appreciation of John Owens, the founder of Owens College Martchester, now the University of Man-

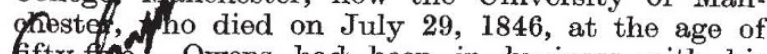
ifty-ffer. Owens had been in business with his fay of as a furrier and a maker of hat linings, but had afterwards engaged in other business enterprises, and, being a bachelor of simple tastes and abstemious habits, had accumulated a considerable fortune which it is said he wished to leave to his closest friend, George Faulkner. But of the money Faulkner would have none; he prevailed upon Owens to make a will leaving his fortune for educational purposes. An institution was to be set up at or near Manchester for the instruction of young persons in such branches 
of learning and science as "are now or may be hereafter taught in the English universities", but subject to "the fundamental and immutable rule and condition" that the professors, officers, students, etc., shall not be required to submit to any religious test whatsoever. Owens's estate realized $£ 168,02510 s .5 d$., and the residue which came to the College was $£ 96,6544 s$. $6 d$. The College was opened in 1851 in William Cobden's old house, and new buildings were erected in 1870-73. Frankland was the first professor of chemistry, and in 1857 he was succeeded by Roscoe, under whom worked many men afterwards famous. The engineering department was opened in 1868 with Osborne Reynolds as professor of civil and mechanical engineering. "Owens," says Mr. Redford, in the article referred to, "was a plain man with no aspirations to greatness, who builded better than he knew.'s/2

\section{Memorial to John Dalton}

Two years ago, on the pecasion of the centenary of the death of Johr Dabuon (see Nature, 154, 103 ; 1944), the Socie Sriends arranged to erect a memorial sto $6 \theta$ his memory in the quiet graveyard at Pardghaw Låll close by his birthplace, Eaglesfield, near Gollormouth, Cumberland. Dalton was educhted the Quaker School at Eaglesfield and was a tede er there before he removed first to Kendal and then in 1793 to Manchester, where he spent the remainder of his life. At his death on July 27, 1844, he was buried in the public cemetery at Ardwick, but it is considered by some that he would have preferred to be buried in his native county. Owing to the War the plan made in 1944 for a memorial stone had to be postponed, but is now to be carried out. The stone will bear his name, places and dates of birth and death, and the epitaph "Not for an age but for all time: This to his memory".

\section{Mineral Development in Great Britain}

THE Minzster of Fuel and Power has appointed a committbe, to be known as the Mineral Development Comndittee, with the following terms of reference : "To inquire into the resources of minerals in the Znited Kingdom, excepting coal, oil, bedded ironstone, and substances of widespread occurrence; to consider possibilities and means of their co-ordinated, orderly, and economic development in the national interest, and to make recommendations in regard thereto".

The Committee is constituted as follows: Lord Westwood (Chairman); Mr. T. Balogh (Institute of Statistics, University of Oxford); Mr. A. R. Davies (partner in the firm of T. C. Horabin and Partners, industrial consultants); Prof. W. R. Jones (Imperial College of Science and Technology; adviser to Board of Trade (China Clay); chairman, China Clay Working Party); Mr. L. C. Hill (technical adviser to the board of directors of Rio Tinto, Ltd.) ; Prof. A. O,iRankine (chief physicist, Anglo-Iranian Oil Co., Ltd.) ; Prof. J. A. S. Ritson (professor of mining, Royal School of Mines; deputy chairman of the Coal Commission); Mr. Stanley Robson (director of Imperial Smelting Corporation, Ltd.) ; Mr. Tom Steele, M.P. ; Captain. Peter Thorneycroft, M.P.; and Mr. R. E. Yeabsley (partner in the firm of Hill, Vellacott \& Co., chartered accountants). The secretary of the Committee is Mr. W. C. C. Rose, to whom all communications should be addressed at the Ministry of Fuel and Power, 40 Upper Brook Street, London, W.1.

\section{Scientific Posts in the Development of Atomic Energy}

According to the Daily Mail of August 3, Mr. L. J. F. Primble, joint editor of Nature, attacked "Secrec over the appointment of scientists to postg in the development of atomic energy", at a fathering of "scientists at Wadham College, Oxford". This statement is so inaccurate as to convey the opposite of that which $\mathrm{Mr}$. Brimble actually did say. He.was addressing the summer school of the British Social Hygiene Council on "Science and Social Progress". In dealing with atomic energy, Mr. Brimble pleaded that public (especially lay) opinion should be based on more accurate and fuller knowledge. He gave a brief history of atomic research in an attempt to show that no one country could claim all the credit, and emphasized the important pioneer work of Dalton in Manchester followed later by the crucial researches under Rutherford at Cambridge. This, he claimed, should be more widely known, for it might surprise some if they knew how widespread among the lay public was the belief that all atomic research had so far been practically confined to the United States. As regards the appointment of physicists to posts dealing with atomic research, Mr. Brimble neither said nor implied anything. In fact it should here be stated that in the opinion of the Editors of Nature, such posts as exist in Britain are held by the most suitable and competent men of science, and, so far as they are aware, there has been no "secrecy" in appointing them. Mr. Brimble did, however, direct attention to the hasty decisions being made in appointing personnel to certain scientific and educational bodies-decisions which seem to be made by a few without consulting other authorities-and often not followed by any published announcement of such appointments. Those bodies which Mr. Brimble had in mind are far removed from atomic energy, or indeed any other kind of scientific research.

$$
1012
$$

\section{Pharmaceutical Products and their Manufacture}

Mr. B. A. BurJ in his address as chairman to the British Phar orteal Conference meeting in London on July 16, Reviefed the various fields of develop$m$ ht in pharmaceutical practice which have occurred d fuphg the past ten or fifteen years. A good deal of attention has been devoted to methods of analytical control, particularly the extension of physical methods, such as spectroscopic, adsorption, fluorimetric, X-ray and the selenium cell. The technique of microanalysis had been developed so that routine examinations can be carried through with a considerable degree of both speed and accuracy. Adsorption has been applied in the development of chromatography. The range of synthetic chemical compounds having medicinal properties has been widely extended and, in addition to the synthesis of naturally occurring substances such as the vitamins and the development of fermentation, and biological processes, whole series of new compounds possessing marked physiological activity have been prepared. The search for true chemotherapeutic agents has proceeded with increased vigour and with considerable success, notably in the case of penicillin.

Many new developments have occurred in the basic processes underlying manufacturing processes. Thus with vacuum evaporators, the design has tended to emphasize the advantage of rapid circulation of the liquid with a consequent diminution in 